\title{
Digitalization in education during the COVID-19 pandemic: emergency distance anatomy education
}

\author{
Serdar Babacan ${ }^{1,3}$ (1) Semahat Dogru Yuvarlakbas ${ }^{2,4}$ () \\ Received: 4 June 2021 / Accepted: 26 August 2021 / Published online: 2 September 2021 \\ (c) The Author(s), under exclusive licence to Springer-Verlag France SAS, part of Springer Nature 2021
}

\begin{abstract}
Purpose During the COVID-19 pandemic, the distance education method started to be applied to prevent the interruption of education in universities. Anatomy education given to students who will serve in the field of health has also been transferred to the online method in this digitization process. The aim of the study was to evaluate the emergency distance anatomy education by taking the feedback of the students of the health services vocational school and to make changes and regulations that will increase the quality of education.

Methods In the study, a questionnaire was applied to Harran University Health Services Vocational School students. The link address of the online survey (prepared 5-point Likert scale) form was shared with the volunteers. SPSS 20.0 was performed for the statistical analyses.

Results A total of $75.6 \%$ of the volunteers participated in the study stated that they preferred face-to-face anatomy education to distance anatomy education. $63.3 \%$ of the volunteers stated that distance anatomy education provides flexibility and time saving, $65.5 \%$ of them provide the opportunity to learn at their own learning pace. $63.1 \%$ of the participants stated that they could not get their attention due to not being in the classroom environment.

Conclusion To increase the efficiency and quality of distance anatomy education for students studying in the field of health, it is necessary to take into account the feedback received from the students and to make adjustments in the curriculum and content by considering the feedback.
\end{abstract}

Keywords COVID-19 $\cdot$ Digitalization in education $\cdot$ Distance anatomy education $\cdot$ Emergencydistance education

\section{Introduction}

The unexpectedly expeditious spread of the COVID-19 pandemic since the beginning of 2020 has caused unprecedented changes in the economic, social, and educational fields globally [6, 24]. In many countries, it has become one

Serdar Babacan

sbabacan@harran.edu.tr

Semahat Dogru Yuvarlakbas

semahatdogru@hotmail.com

1 Department of Anatomy, Medical Faculty, Harran University, Şanlıurfa, Turkey

2 Vocational School of Health Service, Harran University, Şanlıurfa, Turkey

3 Tıp Fakültesi Anatomi Anabilim Dalı Osmanbey Kampüsü, Harran Üniversitesi, Şanlıurfa, Turkey

4 Sağlık Hizmetleri Meslek Yükssekokulu Yenişehir Kampüsü, Harran Üniversitesi, Şanlıurfa, Turkey of the most important problems that the governments should consider how to continue face-to-face education that serves to a significant part of the population [9]. To contribute to the prevention of the epidemic, it has been decided to suspend education in a short time in many countries and then to start distance education [22]. With the COVID-19 outbreak, for the first time in history, a student group of this scale has been deprived of face-to-face education at school, and it is very difficult to predict how long this process will take [20].

The first case was detected on 11 March 2021 in Turkey. As of March 16, 2020, education was suspended for three weeks at universities. Then it was decided to continue the spring semester with distance education $[17,18]$. However, the rapid transition from face-to-face education to distance education without having to discuss the benefits and limitations of distance education has brought some problems with it [22]. In fact, distance education is a process that requires a devoted planning, design, and technical infrastructure that lays the groundwork for an effective 
teaching process. During the COVID-19 pandemic process, distance education was suddenly started without having sufficient experience and infrastructure. To eliminate the conceptual confusion caused by this rapid transition, researchers found the concept of "emergency distance education" more appropriate to separate it from the known distance education $[7,14,30]$.

Today, due to social and technological changes, the health needs of individuals who make up society also change. In order for health services to be effective, efficient, and sufficient, it is important that health sciences students, who will work in this field, receive a qualified education [12]. All healthcare professionals who perform invasive procedures on patients, perform emergency interventions, deal with radiological imaging, and similar fields can communicate with each other only if they have a common medical terminology and anatomy terminology plays an important role in health communication as a common language $[4,11]$.

Anatomy is accepted as the "basis of health sciences" in order to gain the success of health education students in other courses, the quality of their studies, and the behaviors that need to be acquired. Therefore, in order for healthcare providers to have a good basic knowledge infrastructure, it is necessary to acquire knowledge of anatomy $[1,15]$. In addition to transferring academic knowledge, anatomy education is the first lesson in which students encounter the human body and organs. In this respect, it has a very important place in making students feel that they are educated in the field of health $[3,16]$.

Education, which is a dynamic process, should accept the changes and improvements that can be brought when needed according to the conditions of the time. Although adapting to changes in this process causes problems, problems disappear or decrease over time [3]. In the process of COVID-19 pandemic for anatomy education, it has become mandatory to use innovative teaching strategies and techniques such as video-based learning, team-based learning, and peer teaching. In this way, it is thought that anatomy education can be more interactive and interesting with active and innovative learning methods that put the student in the center and include it in education [25].

In education, which is constantly changing and innovating, the feedback received from students is as valuable as the feedback of the faculty members to determine the quality of teaching, to complete the deficiencies, and to correct the mistakes [19].

The aim of the study was to evaluate the efficiency of anatomy education given by distance education during the COVID-19 pandemic, taking into account the feedback received from students, and to make the necessary arrangements to increase the effectiveness and efficiency of distance anatomy education in case it continues or is applied again.

\section{Materials and methods}

Ethics committee approval was obtained for the study from the Ethics Committee of Harran University, with the date of 01.02.2021 and the number of HRU / 21.03.17. In the study, an online questionnaire form was proposed to the students of Harran University's Health Services Vocational School who attended distance anatomy education in the fall semester of the 2020-2021 academic year.

The survey questions were prepared to be applied online via google forms. The link address of the online questionnaire was shared with the students in the class online communication groups through the class representatives. Participation in the evaluation questionnaire was voluntary. There were no sanctions or directions for answering the questionnaire. Reading the "Volunteer Consent Form" on the first page of the questionnaire and ticking the consent button "I accept" was mandatory to start the survey. 279 volunteers participated in the online survey.

In terms of the reliability of the answers to the questionnaire, no questions were asked that could determine the identity of the respondent in the questionnaire. The response time to 5-Likert type questionnaire questions about socio-demographic information and thoughts about distance anatomy education has been detected to be 6 min on average.

In the questionnaire form, the participants were asked to compare face-to-face anatomy education with online anatomy education and to determine the advantages and limitations of online anatomy class.

For the distinction between the students who attended distance anatomy lessons for 0-9 weeks were divided into Group A, and those who attended 10 weeks or more were Group B, taking into account the duration of attending the lessons in face-to-face education.

As the questions were proposed to the students in the form of the survey, we recollected and analyzed the received answers in percentages. Frequency distribution of the categorical responses to the questions was included, as well as the scoring of the answers.

( 1 = Strongly Disagree, $2=$ Disagree, $3=$ Undecided, $4=$ Agree, $5=$ Strongly Agree) .

Mean and standard deviation values were calculated in order to evaluate the answers given to the questions statistically. The obtained results demonstrated that the values calculated between 0 and 2.4 were evaluated as negative opinion, the values between 2.5 and 3.4 were evaluated as undecided opinion and the values calculated between 3.5 and 5.0 were evaluated as positive opinion. SPSS 20.0 (Statistical Package for the Social Sciences) was performed for the comparative statistical analysis between the groups. Shapiro-Wilk normality test was used for the 
normal distribution tests of the groups. The independent sample t-test (Student's $T$ test) was applied to compare normally distributed groups. A one-way analysis of variance (One-Way ANOVA) test was used to compare multiple groups. Statistical significance was taken as $p<0.05$.

\section{Results}

A total of 279 volunteer students, 197 females (70.6\%) and 82 males (29.4\%), participated in the study.

$13.3 \%$ of the volunteers participating in the study were Operating Room Services, 13.3\% Anesthesia Technician, 7.9\% Pharmacy Services, 25.4\% First and Emergency Aid, $11.1 \%$ Podology, $12.9 \%$ were trained in Medical Imaging Techniques, $8.2 \%$ in Dialysis, 7.9\% in Orthopedic Prosthetic Orthotics programs.

$51.3 \%$ of the volunteers stated that they lived in the city center, $11.8 \%$ in the central district, $18.6 \%$ in the district, $0.4 \%$ in the town, and $17.9 \%$ in the village.

$70.6 \%$ of the participants stated that there was internet resource in their place of residence, $29.4 \%$ of them stated that there was no internet resource in the place where they live.

$73.5 \%$ of the participants take remote anatomy lessons from a smartphone, $8.2 \%$ from their own computer, $6.8 \%$ from someone else's computer, $0.7 \%$ from their own tablet,
$1.1 \% 9.7 \%$ declared that they could not follow the lessons while watching from someone else's tablet.

While the rate of volunteers (Group A) attending distance anatomy lessons for $0-9$ weeks was $58.95 \%$, the rate of volunteers (Group B) attending 10 weeks or more was $41.5 \%$.

The percentage frequency distribution of the answers given to the 5-point Likert type questionnaire about distance anatomy education and the average and standard deviation values obtained by scoring over 5 points are given in Table 1 .

Independent Sample $T$ Test (Student's $T$ test) was applied as both groups showed normal distribution in the comparative statistics between Group A and Group B. As a result of the comparison, a statistically significant difference was observed between Group A with a mean of $54.64 \pm 1.45$ and Group B with a mean of $69.65 \pm 1.58(p=0.000)$.

The Grade Point Average (GPA) of the participants who could not attend the distance anatomy lessons but watch the lessons they missed from the offline video recordings was $62.30 \pm 17.31$, while the GPA of the volunteers who did not watch the video recordings of the lessons they missed was calculated as $54.92 \pm 12.51$ and the Independent Sample $T$ Test as a result of the (Student's $T$ test), a statistically significant difference was observed between the two groups $(p=0.008)$.

As a result of the one-way analysis of variance (OneWay ANOVA) between income levels and grade averages, no statistically significant difference was observed between income levels and grade averages $(p=0.104)$.

Table 1 Frequency distribution percentages, mean and standard deviation score values of the answers given to the questionnaire

\begin{tabular}{|c|c|c|c|c|c|c|}
\hline Questions & $1(\%)$ & $2(\%)$ & $3(\%)$ & $4(\%)$ & $5(\%)$ & Mean \pm SD \\
\hline 1. I prefer anatomy lessons to be go on remotely & 52 & 24 & 12.9 & 7.2 & 3.9 & $1.87 \pm 0.13$ \\
\hline 2. I prefer to have face-to-face anatomy lessons & 6.5 & 5.7 & 12.5 & 25.1 & 50.2 & $4.07 \pm 1.19$ \\
\hline 3. I watched the recordings of the distance anatomy lessons that I did not attend & 3.9 & 17.2 & 13.3 & 41.9 & 23.7 & $3.64 \pm 1.13$ \\
\hline $\begin{array}{l}\text { 4. It is more advantageous to be able to watch the recordings of the distance anatomy lessons } \\
\text { that I could not attend, compared to face-to-face education }\end{array}$ & 13 & 12.9 & 17.2 & 21.5 & 35.4 & $3.53 \pm 1.48$ \\
\hline 5. Distance anatomy education is a more effective learning method & 51.6 & 26.2 & 15.1 & 5 & 2.2 & $1.79 \pm 1.01$ \\
\hline 6. Face-to-face anatomy training is a more effective learning method & 7.2 & 4.7 & 11.8 & 28.3 & 48 & $4.05 \pm 1.19$ \\
\hline $\begin{array}{l}\text { 7. I could not focus my attention because there was no classroom environment in remote } \\
\text { anatomy lessons }\end{array}$ & 6.5 & 13.3 & 17.2 & 24.7 & 38.4 & $3.75 \pm 1.26$ \\
\hline 8. Remote anatomy training saved flexibility and time & 7.6 & 15.1 & 14 & 26.5 & 36.8 & $3.79 \pm 1.21$ \\
\hline 9. It made my learning anatomy at a distance education more permanent & 36.9 & 29.7 & 20.1 & 9 & 4.3 & $2.13 \pm 1.14$ \\
\hline 10. Remote anatomy training enabled me to learn the transferred information at my own speed & 6.5 & 11.5 & 21.5 & 25.1 & 35.4 & $3.61 \pm 1.26$ \\
\hline $\begin{array}{l}\text { 11. I could not learn efficiently because there was no opportunity to come together and work } \\
\text { with friends in distance anatomy education }\end{array}$ & 5.7 & 14.7 & 14.3 & 31.2 & 34.1 & $3.73 \pm 0.23$ \\
\hline 12. Distance anatomy education is an adequate and effective learning model & 40.9 & 25.1 & 23.3 & 8.2 & 2.5 & $2.06 \pm 1.09$ \\
\hline 13. Lesson time was sufficient in distance anatomy education & 10.4 & 12.2 & 28.3 & 40.1 & 9 & $3.25 \pm 1.11$ \\
\hline 14. Lesson time should have been longer in distance anatomy education & 9.3 & 34.4 & 26.9 & 9 & 9.3 & $2.85 \pm 1.12$ \\
\hline 15. Lesson time should be shorter in distance anatomy education & 11.5 & 41.9 & 30.1 & 10.8 & 5.7 & $2.57 \pm 1.01$ \\
\hline $\begin{array}{l}\text { 16. I think there is no difference between distance anatomy training and face-to-face anatomy } \\
\text { training }\end{array}$ & 52 & 25.8 & 10.4 & 6.8 & 5 & $1.87 \pm 1.55$ \\
\hline
\end{tabular}

1 strongly disagree, 2 disagree, 3 undecided, 4 agree, 5 strongly agree 
While the course follow-up of the volunteers working in any job was calculated as $5.78 \pm 0.58$ weeks, the course follow-up of those who did not work was calculated to be $8.33 \pm 0.27$ weeks, and a statistically significant difference was found between the course follow-up period of the two groups $(p=0.000)$. It was calculated to be $65.68 \pm 25.13$ for those who did not work with a GPA calculated as $49.26 \pm 15.72$ for the employees.

According to the results of the mean and standard deviation (respectively) and the values of the answers given to the survey questions, the value of the question related to online anatomy education was $1.87 \pm 0.13$. On the other hand, the value of the question related to face-to-face education was determined to be $4.07 \pm 1.19$. As reported by the results, it was determined that the participants preferred face-to-face anatomy education to distance remote process. The value of the answers stating that they watched the missed lessons from the recording was $3.64 \pm 1.13$. Additionally, the value of the question about watching the course records later was calculated as $3.53 \pm 1.48$. According to the final result, the participants expressed that they thought it as an advantage that the recorded online courses can be watched later. The value of the answers given to the question that online anatomy education was more effective was $1.79 \pm 1$.0.At the same time, the value of the answers given to the question that face-to-face anatomy education was more effective and was calculated as $4.05 \pm 1.19$. In line with these results, the participants expressed the opinion that face-to-face anatomy education was more effective. The value of the question stated as "I couldn't concentrate, because there was no classroom environment" was calculated as $3.75 \pm 1.26$. In keeping with the data, the participants stated the lack of a classroom environment, as a limitation. The value of the question about the flexibility of online anatomy education in terms of place and time was calculated as $3.79 \pm 1.21$. According to this result, the participants stated that online education provides flexibility in terms of place and time, as an advantage.

\section{Discussion}

Although the COVID-19 outbreak is the first epidemic affecting existing anatomy students, it is possible to take an example of the experiences from previous crises in terms of not interrupting education. Information technologies were integrated into education in Hong Kong during the SARS epidemic in 2003, and a web-based education model was implemented to minimize the disruption in education received by students $[13,23]$. Similarly, the COVID-19 outbreak caused face-to-face teaching to be suspended in universities and the transfer of anatomy lessons to virtual environments [28].
E-learning or distance education is a teaching method supported by digital technologies, as emphasized by the definition of "Using new multimedia technologies and the internet to improve the quality of learning by facilitating remote information exchange as well as access to resources and services" $[2,28]$. The method has advantages such as saving time, having the flexibility to participate in the lesson from anywhere, the opportunity to repeat the recorded lessons, and the ability to watch the missed lecture again from the recording. The disadvantages of the method are that it is difficult for students who do not have sufficient self-discipline to perform the necessary activities without an educator to guide and supervise and that it is not possible to ask questions in non-synchronous and subsequently listened lessons [10]. In addition, students' socioeconomic status or access opportunities can cause a limitation in distance education [30].

As a result of the study conducted by Başaran et al. in 2020 , on the effectiveness of distance education, which is the return of the COVID-19 pandemic process, the volunteer students who participated in the study determined that distance education provided the opportunity to continue education during the pandemic process, offered the opportunity to repeat and reinforce, and its flexible structure as the main advantages. They considered the lack of immediate feedback, not being a substitute for face-to-face training, not providing a basis for socialization, technical problems, and focusing problems among its main disadvantages [5].

In the study, in which Turhan and Yakut consulted physiotherapy students about distance anatomy education in the COVID-19 period in 2020, $53.1 \%$ of the participants answered positively and stated that they "understood and learned anatomy in online lessons", while $15.7 \%$ of the participants gave a negative response. $31.3 \%$ remained undecided. To the question "Online anatomy education is as effective as face-to-face education", the participants responded with $12.5 \%$ strongly agree, $21.9 \%$ agree, $15.6 \%$ undecided, $31.3 \%$ disagree and $18.8 \%$ strongly disagree. $54.7 \%$ of the participants gave a negative answer to the question "I prefer anatomy education online", $12.5 \%$ were undecided and $32.8 \%$ answered positively [29].

Senol et al. evaluated the feedback from students about distance anatomy education in 2021. In their study, 30.4\% of the dentistry students who voluntarily participated in the study and $28.6 \%$ of the medical faculty students gave feedback as follows: "If I had the chance to choose, I would prefer distance anatomy education". To the question: "I think that anatomy theoretical lessons should be taught online when the pandemic is over", $33.9 \%$ of the volunteers of the dental faculty of dentistry and $36 \%$ of the participants who are the medical faculty students, strongly disagree [26].

Cuschieri and Agius conducted a study on distance anatomy education in Malta in 2020, based on the opinions of 
medical faculty students. As a result of the study, half of the participants stated that they thought the effect of distance education and face-to-face education was equal. The advantages of the method include reducing the anxiety of taking notes, providing the opportunity to listen to the recorded lecture again when there is an incomprehensible subject, allowing students to learn at their own pace, and saving time spent on the road [8].

Singal et al. surveyed the potential challenges of digital anatomy education on medical and dental students in 2020, in India. As the feedback of the students, $65 \%$ of the participants stated that they missed every aspect of the anatomy education. $58 \%$ of the students expressed that they preferred distance education by video-recorded classes. $68 \%$ of the volunteers said that they had difficulty in time management, $69 \%$ of them denoted that they felt a lack of self-motivation [27].

As the result of the study of Ortadeveci et al., conducted on 239 medical students in 2021 in Turkey, 27.2\% of the participants strongly disagreed, $23.0 \%$ disagreed, $25.9 \%$ were neutral, $16.3 \%$ agreed and $7.5 \%$ totally agreed with the question of distance anatomy education enables students to learn at their own pace [21].

In our study, $77.8 \%$ of the participants in total stated that there was a difference between distance anatomy education and face-to-face education; while $76 \%$ of them do not prefer distance anatomy education, $75.6 \%$ of them stated that they prefer face-to-face anatomy education. While $65.6 \%$ of the volunteers stated that they watched the records of the distance anatomy lessons that they could not attend later, $56.9 \%$ of them stated that they found it more advantageous to watch the course registrations later than face-to-face education. $63.3 \%$ of the participants stated that distance anatomy education provides space flexibility and time saving; $60.5 \%$ of them stated that they learned the information transferred by distance anatomy education at their own pace. The volunteers stated that $63.1 \%$ of the volunteers could not pay attention in distance anatomy education due to not being in the classroom environment; $65.3 \%$ of them gave feedback that they could not learn efficiently because they did not have the opportunity to come together and work with their friends.

\section{Conclusion}

Distance education is a process that requires training planning and design to be prepared by experts. During the COVID-19 pandemic period, the difference between the concept of distance education and the concept of emergency distance education should be taken into consideration, since distance education was started without any preparations. In case the problems brought by emergency distance education can be determined and the pandemic process is prolonged, these deficiencies should be eliminated as much as possible. In order for distance education to be advantageous in accordance with its purpose, both educators and students should be aware of the principles of distance education. Since anatomy education is a discipline that requires three-dimensional perception, the course content should be enriched as much as possible. The use of technological applications, such as 3D anatomy atlases, augmented virtual reality, virtual dissection tables, which have entered our lives with the developing technology, should be encouraged. Instead of lecturing directly in online classes, a more interactive method should be used to ensure that students participate in the course and create a classroom environment. According to the course of the adverse conditions experienced, cadaver studies, which are the gold standard of anatomy education, should be arranged in small groups in anatomy laboratories.

Author contributions All authors contributed to the study conception and design. SB and SYD-Project development, SYD-Data collection, SB-Data management and analysis, SB and SYD-Manuscript writing, SYD-Manuscript editing.

Funding The study had no sponsorship.

\section{Declarations}

Conflict of interest The authors declare that they have no conflict of interest.

Ethical approval Ethics committee approval was obtained for the study from the Harran University Ethics Committee with the date of 01.02.2021 and the number of HRU / 21.03.17.

Informed consent Informed consent was obtained from all individuals who participated in the study and only the volunteers were allowed to continue the online survey.

\section{References}

1. Acuner AM, Yalçın M, Ersoy M, Tekdemir İ, Ersoy F (1999) Ankara Üniversitesi tıp fakültesi anatomi dersine ilişkin öğretmeöğrenme sürecinin değerlendirilmesi. Ankara Üniversitesi Tıp Fakültesi Mecmuası 52(04):211-218. https://doi.org/10.1501/ Tipfak_0000000402

2. Alonso F, López G, Manrique D, Viñes JM (2005) An instructional model for web-based e-learning education with a blended learning process approach. Br J Edu Technol 36(2):217-235

3. Arı İ, İrgil E, Kafa İM, Şendemir E (2003) Bir anket çalışması: anatomi eğitimi ve öğrencilerin düşünceleri. Uludağ Üniversitesi Tıp Fakültesi Dergisi 29(2):15-18

4. Babacan S, Işıklar S, Kafa İM, Coşkun İ (2016) Tibbi terminoloji hakkında öğrencilerin ve çalışanların görüşleri. Uludağ üniversitesi Tıp Fakültesi Dergisi 42(2-3):89-92

5. Başaran M, Doğan E, Karaoğlu E, Şahin E (2020) Koronavirüs (COVID-19) pandemi sürecinin getirisi olan uzaktan eğitimin etkililiği üzerine bir çalışma. Academia Eğitim Araştırmaları Dergisi 5(2):368-397 
6. Bozkurt A (2020) Koronavirüs (COVID-19) pandemi süreci ve pandemi sonrası dünyada eğitime yönelik değerlendirmeler: Yeni normal ve yeni eğitim paradigması. Açıköğretim Uygulamaları ve Araştırmaları Dergisi 6(3):112-142

7. Bozkurt A, Sharma RC (2020) Emergency remote teaching in a time of global crisis due to corona virus pandemic. Asian J Distance Educ 15(1):i-vi. https://doi.org/10.5281/zenodo.3778083

8. Cuschieri S, Agius JC (2020) Spotlight on the shift to remote anatomical teaching during COVID-19 pandemic: perspectives and experiences from the University of Malta. Anat Sci Educ 13:671-679. https://doi.org/10.1002/ase.2020

9. Daniel SJ (2020) Education and the COVID-19 pandemic. Prospects 49:91-96. https://doi.org/10.1007/s11125-020-09464-3

10. De Oliveira MMS, Penedo AST, Pereira VS (2018) Distance education: advantages and disadvantages of the point of view of education and society. Dialogia 29:139-152. https://doi.org/10. 5585/dialogia.N29.7661

11. Demir M, Atay E, Kılıç M, İpekçi NN (2014) Kilis 7 Aralık Üniversitesi lisans ve ön lisans eğitiminde öğrencilerin anatomi dersi ile ilgili görüşlerinin karşılaştırılması. Sağlık Bilimleri Dergisi 23(3):144-148

12. DeryaBeydağ K, Gündüz A, GökÖzer F (2008) Sağlık yüksekokulu öğrencilerinin eğitimlerine ve mesleklerine bakış açıları, meslekten beklentileri. Pamukkale Tip Dergisi 1(3):137-142

13. Franchi $T$ (2020) The impact of the COVID-19 pandemic on current anatomy education and future careers: a student's perspective. Anat Sci Educ 13:309-312. https://doi.org/10.1002/ase.1966

14. Hodges C, Moore S, Lockee B, Trust T, Bond A (2020) The difference between emergency remote teaching and online learning. Access adress: https://er.educause.edu/articles/2020/3/the-diffe rence-between-emergency-remote-teaching-and-online-learning

15. Iwanaga J, Loukas M, Dumont AS, Tubbs RS (2020) A review of anatomy education during and after the COVID-19 pandemic: Revisiting traditional and modern methods to achieve future innovation. Clin Anat. https://doi.org/10.1002/ca.23655

16. Kara A, Öğrenler O, Elvan Ö (2012) Anatomi anıları. İnönü Üniversitesi Tıp Fakültesi Dergisi 19(1):54-56

17. Karadağ E, Yücel C (2020) Yeni tip koronavirüs pandemisi döneminde üniversitelerde uzaktan eğitim: lisans öğrencileri kapsamında bir değerlendirme çalışması. Yükseköğretim Dergisi 10(2):181-192

18. Keskin M, Özer Kaya D (2020) COVID-19 sürecinde öğrencilerin web tabanlı uzaktan eğitime yönelik geri bildirimlerinin değerlendirilmesi. İzmir Kâtip Çelebi Üniversitesi Sağlık Bilimleri Fakültesi Dergisi 5(2):59-67

19. Kulik JA (2001) Student ratings: validity, utility and controversy. New Dir Inst Res 109:9-25. https://doi.org/10.1002/ir.1
20. Micks J, and Mcllwaine J (2020) Keeping the world's children learning through COVID-19. UNICEF. https://www.unicef. org/coronavirus/keeping-worlds-children-learning- throughCOVID-19 (ET: 20.05.2020)

21. Ortadeveci A, Ermez MN, Oz S, Ozden H (2021) A survey study on distance anatomy education: challenges unique to anatomy. Surg Radiol Anat. https://doi.org/10.1007/s00276-021-02772-z

22. Özer M, Suna E (2020) COVID-19 salgını ve eğitim, küresel salgının anatomisi insan ve toplumun geleceği, Türkiye Bilimler Akademisi. TDV Yayın Matbaacılık Tesisleri, ANKARA 173-192

23. Patil NG, Chan Ho Yan H (2003) SARS and its effect on medical education in Hong Kong. Med Educ 37:1127-1128. https://doi. org/10.1046/j.1365-2923.2003.01723.x

24. Sadeesh T, Prabavathy G, Ganapathy A (2021) Evaluation of undergraduate medical students' preference to human anatomy practical assessment methodology: a comparison between online and traditional methods. Surg Radiol Anat 43:531-535. https:// doi.org/10.1007/s00276-020-02637-x

25. Saverino D (2020) Teaching anatomy at the time of COVID-19. Clin Anat https://doi.org/10.1002/ca.23616 [Epub ahead of print].

26. Senol D, Toy S, Canbolat M, Pektas M (2021) Evaluation of online anatomy education given in medicine and dentistry faculties of universities during COVID-19 pandemic with student. Konuralp Medical Journal 13(1):30-35. https://doi.org/10.18521/ ktd.757819

27. Singal A, Bansal A, Chaudhary P, Singh H, Patra A (2020) Anatomy education of medical and dental students during COVID-19 pandemic: a reality check. Surg Radiol Anat 43:515-521. https:// doi.org/10.1007/s00276-020-02615-3

28. Srinivasan DK (2020) Medical students' perceptions and an anatomy teacher's personal experience using an e-learning platform for tutorials during the COVID-19 crisis. Anat Sci Educ 13:315-316. https://doi.org/10.1002/ase. 1970

29. Turhan B, Yakut Y (2020) The opinions of physiotherapy students on online anatomy education during COVID-19 pandemic. Anatomy 14(2):134-138

30. Yıldırım $K$ (2020) İstisnai bir uzaktan eğitim-öğretim deneyiminin öğrettikleri. Alanyazın 1(1):7-15

Publisher's Note Springer Nature remains neutral with regard to jurisdictional claims in published maps and institutional affiliations. 